\title{
Further studies of post-partum ovulation timing in mice
}

\author{
Audrey S. Bingel \\ Department of Pharmacognosy and Pharmacology, University of Illinois College of Pharmacy, \\ 833 South Wood Street, Chicago, Illinois 60612, U.S.A.
}

\begin{abstract}
Summary. The times at which post-partum ovulation occurred relative to the times of parturition, were similar for $\mathrm{CD}^{*}-1$ mice exposed either to $18 \mathrm{~L}: 6 \mathrm{D}$ or $10 \mathrm{~L}: 14 \mathrm{D}$ and comparable to the times reported previously for mice of the same strain kept under 14L: 10D. When parturition took place close to 'lights off', ovulation tended to occur 13-14 h after littering (i.e. during the last part of the same dark period and the early part of the next light period). Conversely, when parturition took place closer to 'lights on', ovulation tended to be delayed by the equivalent number of hours so that it occurred during the last part of the next dark period and early part of the subsequent light period. This confirmation and extension of earlier work suggests that mice of this strain would be useful for investigating hormonal events associated with the timing of post-partum ovulation in the mouse.
\end{abstract}

\section{Introduction}

In 1965, Hoffmann \& Schwartz reported a temporal relationship between the day (and time of day) on which rats littered and the day on which post-partum ovulation occurred; they deduced the apparent time of the post-partum ovulatory release of $\mathrm{LH}$ by observing for the occurrence or non-occurrence of ovulation in rats in which they had attempted to block LH release pharmacologically or by means of hypophysectomy. Since then, a number of investigators (e.g. Rebar, Nakane \& Midgley, 1969; Johnson, 1972; Hashizume, Sugawara \& Takeuchi, 1973; Ying, Gove, Fang \& Greep, 1973; Morishige, Pepe \& Rothchild, 1973) have more closely delineated the time of $\mathrm{LH}$ release and/or ovulation in rats after parturition. Similar studies, however, have not been pursued extensively in the mouse.

Runner \& Ladman (1950) reported that Swiss mice exposed to a photoperiod of $6 \mathrm{~h}$ dark: $18 \mathrm{~h}$ light tended to ovulate $18 \mathrm{~h}$ after parturition when the latter took place between $21: 00$ and $01: 00 \mathrm{~h}(00: 00 \mathrm{~h}=$ midpoint of dark period), and that the parturition to ovulation interval progressively decreased the later (after 01:00 h) that parturition occurred, until it became 12-13 h for mice littering between 17:00 and 21:00 h. Subsequently, Bingel \& Schwartz (1969b) reported that $C D^{*}-1$ mice exposed to $14 \mathrm{~L}: 10 \mathrm{D}$ (lights on 05:00-19:00 h) tended to ovulate approximately $26 \mathrm{~h}$ after parturition when the latter took place between 21:00 and $01: 00 \mathrm{~h}$, the interval decreasing to $13 \mathrm{~h}$ for mice littering between 17:00 and 21:00 h. In both studies, LH release presumably occurred at about the time of parturition for mice giving birth between 17:00 and $21: 00 \mathrm{~h}$, but this has not been tested. The purpose of the present study was to determine the time of post-partum ovulation in $\mathrm{CD}^{*}-1$ mice kept under 2 different light:dark ratios (18L:6D and 10L:14D) and to compare the results with those reported previously for Swiss mice exposed to 6D:18L (Runner \& Ladman, 1950), and for CD*-1 mice exposed to 14L:10D (Bingel \& Schwartz, 1969b). 


\section{Materials and Methods}

Six-week-old virgin female albino $\mathrm{CD}^{*}-1$ mice were obtained from Charles River Mouse Farms and housed individually, in environmentally controlled quarters which provided either $18 \mathrm{~h}$ light per 24-h period (lights on 03:00-21:00 h, Exp. 18L:6D) or $10 \mathrm{~h}$ light per 24-h period (lights on 07:00-17:00 h, Exp. 10L:14D). Vaginal smears were taken as previously reported (Bingel \& Schwartz, 1969a), beginning 2 weeks after the animals had arrived in the laboratory; mating was permitted on an evening of pro-oestrus when the females were between 10 and 18 weeks of age. The male was removed from the female's cage the following morning, and the latter was designated Day 1 of pregnancy if a copulation plug was present in the vagina. Vaginal smears were discontinued when a $2-\mathrm{g}$ increase in weight was observed.

Beginning late on Day 18, mice were observed at 4-h intervals for the occurrence of parturition, thus creating the following littering time groups: $\mathrm{A}, 21: 00-01: 00 \mathrm{~h} ; \mathrm{B}$, $01: 00-05: 00 \mathrm{~h} ; \mathrm{C}, 05: 00-09: 00 \mathrm{~h} ; \mathrm{D}, 09: 00-13: 00 \mathrm{~h} ; \mathrm{E}, 13: 00-17: 00 \mathrm{~h}$; and F, 17:00-21:00 h. The young were removed after parturition was completed. The time of ovulation for mice in each group was determined by observing their oviducts at laparotomy under ether anaesthesia (Bingel \& Schwartz, 1969a); when swollen, transparent oviducts were observed, the mice were killed and the ova from both oviducts counted. The times selected for laparotomy were based on the intervals during which ovulation had occurred in mice littering at similar times, respectively, in the 2 previous studies (Runner \& Ladman, 1950; Bingel \& Schwartz, 1969b). Depending, in general, on the group to which a given mouse belonged, the animal was subjected to 1 or 2 (occasionally more) preovulatory laparotomies before its post-ovulatory autopsy; the time of ovulation for each mouse was therefore accurate to within $6 \mathrm{~h}$ (see Tables 1 and 2 and Text-fig. 1). In some animals, ovulation had already occurred by the time of the first laparotomy. In such cases, one ovary and oviduct were removed at that time, and the second approximately $8 \mathrm{~h}$ later. Histological comparison of these tissues permitted estimation of the time at which ovulation had taken place (Bingel, 1968).

\section{Results}

The results are given in Tables 1 and 2. Although some variations in ovulation time are evident among animals within the groups, there was substantial similarity between the times at which the majority of mice within comparable groups ovulated under both lighting regimens. In both photoperiods the interval between parturition and ovulation was about $26 \mathrm{~h}$ for many of the mice in Group A, and progressively decreased to a 13-h interval for most of those in Group F. The major deviations from this trend, as can be seen in Tables 1 and 2, were (a) the markedly early ovulation which occurred in about a third of the mice in Group A, and (b) the approximately 24-h delay in ovulation which occurred in a small number of mice in Groups C, E and F relative to the time at which ovulation took place in most of the mice belonging to these groups.

The results from Tables 1 and 2 have been combined and are presented in Text-fig 1 . The majority of parturitions under both lighting regimens occurred between 09:00 h on Day 19 and $09: 00 \mathrm{~h}$ on Day 20, approximately half before and half after 21:00 h on Day 19, a distribution not unlike that seen for $C D^{*}-1$ mice mated on the evening of pro-oestrus under $14 \mathrm{~L}: 10 \mathrm{D}$ (Bingel \& Schwartz, 1969b; A. S. Bingel, unpublished observations). The Group C mouse which littered between 05:00 and 09:00 h on Day 19, yet ovulated at a time comparable to that at which the other Group C mice ovulated, had one of the largest litters (16 live young, compared with 11.2 for the overall mean, and 12 for both mode and median); an inverse relationship between litter size and duration of pregnancy has been documented (Biggers, Curnow, Finn \& McLaren, 1963). Data for 2 additional mice which littered later than 13:00 h on Day 20 are not shown in the figure: one, a Group B mouse (included in Table 2) delivered 4 young on the 
Table 1. Time of post-partum ovulation in $C D^{*}-1$ mice exposed to $18 \mathrm{~L}: 6 \mathrm{D}$

\begin{tabular}{|c|c|c|c|c|}
\hline \multicolumn{2}{|c|}{ Parturition } & \multirow{2}{*}{$\begin{array}{l}\text { Ovulation } \\
\text { time } \\
\text { (h) }\end{array}$} & \multirow{2}{*}{$\begin{array}{l}\text { Parturition —ovulation } \\
\text { interval* } \\
\text { (h) }\end{array}$} & \multirow{2}{*}{$\begin{array}{l}\text { No. of } \\
\text { mice }\end{array}$} \\
\hline Group & Time (h) & & & \\
\hline A & $21: 00-01: 00$ & $\begin{array}{l}11: 00-13: 00 \\
21: 00-05: 00 \\
05: 00-11: 00\end{array}$ & $\begin{array}{l}13 \\
26 \\
33\end{array}$ & $\begin{array}{l}4 \dagger \\
8 \dagger \ddagger \\
3\end{array}$ \\
\hline B & $01: 00-05: 00$ & $\begin{array}{l}23: 00-05: 00 \\
05: 00-09: 00\end{array}$ & $\begin{array}{l}23 \\
28\end{array}$ & $\begin{array}{r}10 \\
1\end{array}$ \\
\hline $\mathrm{C}$ & $05: 00-09: 00$ & $\begin{array}{l}20: 00-02: 00 \\
02: 00-05: 00 \\
20: 00-02: 00\end{array}$ & $\begin{array}{l}16 \\
20 \cdot 5 \\
40\end{array}$ & $\begin{array}{l}6 \dagger \\
3 \\
1\end{array}$ \\
\hline $\mathrm{D}$ & $09: 00-13: 00$ & $23: 00-05: 00$ & 15 & $6 \ddagger$ \\
\hline $\mathbf{E}$ & $13: 00-17: 00$ & $\begin{array}{l}02: 00-08: 00 \\
08: 00-11: 00 \\
21: 00-05: 00 \\
05: 00-10: 00\end{array}$ & $\begin{array}{l}14 \\
18 \cdot 5 \\
34 \\
40 \cdot 5\end{array}$ & $\begin{array}{c}12+\ddagger \\
3+ \\
1+ \\
1\end{array}$ \\
\hline$F \S$ & $17: 00-21: 00$ & $\begin{array}{l}05: 00-11: 00 \\
21: 00-05: 00 \\
05: 00-11: 00\end{array}$ & $\begin{array}{l}13 \\
30 \\
37\end{array}$ & $\begin{array}{c}17 \ddagger \\
2 \\
1\end{array}$ \\
\hline
\end{tabular}

* The no. of hours between the mid-points of the littering and ovulation periods.

$\dagger 2$ Group A, 2 Group C and 3 Group E mice were ovulating at the time of autopsy.

$\ddagger$ One mouse in each of these subgroups produced approximately half their litter during the period indicated, and half during the subsequent period.

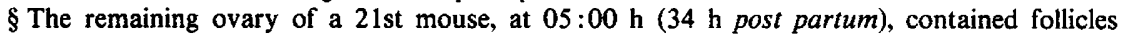
comparable in appearance to those typically seen approximately $12 \mathrm{~h}$ prior to ovulation (Bingel, 1968).

Table 2. Time of post-partum ovulation in $\mathrm{CD}^{*}-1$ mice exposed to 10L : 14D

\begin{tabular}{|c|c|c|c|c|}
\hline \multicolumn{2}{|c|}{ Parturition } & \multirow{2}{*}{$\begin{array}{l}\text { Ovulation } \\
\text { time } \\
\text { (h) }\end{array}$} & \multirow{2}{*}{$\begin{array}{l}\text { Parturition-ovulation } \\
\text { interval } \\
\text { (h) }\end{array}$} & \multirow{2}{*}{$\begin{array}{c}\text { No. of } \\
\text { mice }\end{array}$} \\
\hline Group & Time (h) & & & \\
\hline A & $21: 00-01: 00$ & $\begin{array}{l}11: 00-13: 00 \\
21: 00-05: 00 \\
05: 00-08: 00\end{array}$ & $\begin{array}{l}13 \\
26 \\
31 \cdot 5\end{array}$ & $\begin{array}{l}7^{*} \\
7^{*} \dagger \\
2\end{array}$ \\
\hline B & $01: 00-05: 00$ & $\begin{array}{l}23: 00-05: 00 \\
05: 00-08: 00\end{array}$ & $\begin{array}{l}23 \\
27 \cdot 5\end{array}$ & $\begin{array}{c}11+ \\
2\end{array}$ \\
\hline $\mathrm{C}$ & $05: 00-09: 00$ & $05: 00-08: 00$ & $23 \cdot 5$ & 2 \\
\hline D & $09: 00-13: 00$ & $23: 00-05: 00$ & 15 & $13^{*+}$ \\
\hline $\mathbf{E}$ & $13: 00-17: 00$ & $\begin{array}{l}02: 00-08: 00 \\
23: 00-05: 00\end{array}$ & $\begin{array}{l}14 \\
35\end{array}$ & $\begin{array}{l}7 \\
1\end{array}$ \\
\hline $\mathrm{F}$ & $17: 00-21: 00$ & $\begin{array}{l}05: 00-11: 00 \\
05: 00-11: 00\end{array}$ & $\begin{array}{l}13 \\
37\end{array}$ & $\begin{array}{c}11^{*} \\
1\end{array}$ \\
\hline
\end{tabular}

* Four Group A mice and 1 mouse each of Groups D and F were ovulating at the time of autopsy.

+ Two mice each of Groups A, B and D produced approximately half their litter during the period indicated, and half during the subsequent period. 
morning of Day 21 and the other produced only 1 young, between 23:00 h on Day 20 and $03: 00 \mathrm{~h}$ on Day 21 (Exp. 18L:6D). Both mice ovulated approximately $24 \mathrm{~h}$ after parturition, as did the majority of mice littering between 21:00 h on Day 19 and 05:00 h on Day 20.

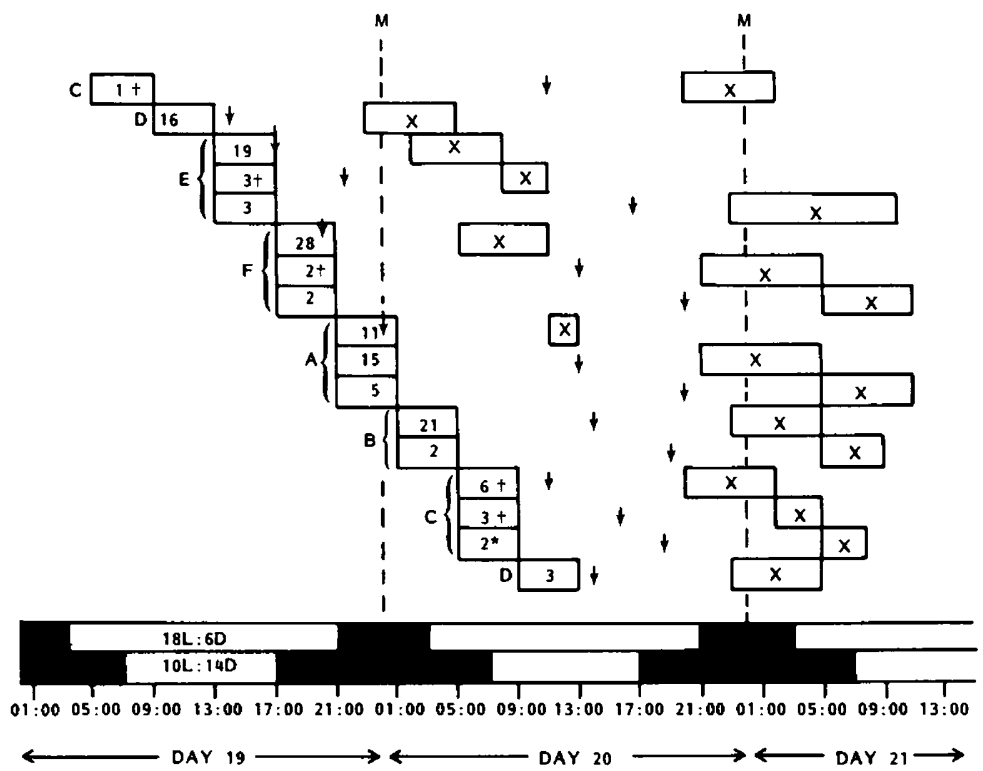

Text-fig. 1. Time of post-partum ovulation in mice. Lettered boxes indicate the times of parturition for the mice in Groups A-F. Numbers therein indicate the number of mice in each group which ovulated during the time intervals represented by the $\mathrm{X}$-containing boxes $(\mathrm{X}=$ midpoint of ovulation period). $\downarrow=$ Presumed time of LH release, estimated as $12 \mathrm{~h}$ before the midpoint of each ovulation period (Edwards \& Gates, 1959). $\mathrm{M}=$ midpoint of dark period for both lighting regimens. Except where indicated $\left(+=18 \mathrm{~L}: 6 \mathrm{D}\right.$. only: ${ }^{*}=10 \mathrm{~L}: 14 \mathrm{D}$. only), the data include observations made in both lighting regimens.

\section{Discussion}

The results indicate a reasonably consistent time of post-partum ovulation in $\mathrm{CD}^{*}-1$ mice, relative to their time of parturition within the range of $\mathrm{L}: \mathrm{D}$ ratios studied. Thus, both the similarities and differences previously reported between CD*-1 (Bingel \& Schwartz, 1969b) and Swiss (Runner \& Ladman, 1950) mice are again in evidence. For example, the parturitionto-ovulation intervals remained comparable for Groups D, E and F, respectively. However, the 18- 17- and 16-h average parturition-to-ovulation intervals reported for Swiss mice in Groups A, B and C, respectively, exposed to $6 \mathrm{D}: 18 \mathrm{~L}$, were not observed for $\mathrm{CD}^{*}-1$ mice in Groups A and B, and only for some Group C mice (see Table 1) exposed to the same (but not reversed) $\mathrm{L}: \mathrm{D}$ ratio.

Approximately half of the Swiss mice in the equivalents of Groups B-F had ovulated by 17, $16,15,14$ and $12-13 \mathrm{~h}$, respectively, after littering (Runner \& Ladman, 1950) compared with $23,19(?), 15,14$ and $13 \mathrm{~h}$, respectively, for the majority of $C D^{*}-1$ mice (see Text-fig. 1 and Bingel \& Schwartz, 1969b); because parturitions in Group C mice are somewhat underrepresented by $C D^{*}-1$ mice, the parturition-to-ovulation interval indicated above should be considered only an approximation. For the small number of mice among Groups B-F not ovulating at the intervals indicated, ovulation was delayed by a few hours or by a full $24 \mathrm{~h}$ (see Tables 1 and 2 and Text-fig. 1). 
Group A mice appear to hold a pivotal position (see Text-fig. 1). Approximately a third of this group behaved as did the majority of mice in Group F, ovulating slightly later than did most Group F mice. The first laparotomy time for Group A mice was 13:00 h, but histological examination of the ovaries and oviducts of the 11 early ovulators indicated that, in most cases, ovulation had occurred just before 13:00 h. The other two-thirds of Group A mice behaved as did those of Group B and ovulated over a similar time span. The proportion of Group A early ovulators did not differ significantly between Exps 18L:6D (Table 1) and 10L:14D (Table 2) (4/15 versus $7 / 16, P>0.05$ : Mainland, Herrera \& Sutcliffe, 1956).

That Group A was also pivotal under 14L:10D (Bingel \& Schwartz, 1969b) is suggested by the fact that 1 saline-treated and 2 untreated animals had already ovulated by the 'pre-ovulatory' laparotomy time for that group. However, 2 Group B mice (1 saline-treated and 1 untreated) were also early ovulators in that study. Unfortunately, histological methods were not employed to estimate more closely when ovulation had occurred in those 5 mice.

A pivotal position was also noted by Runner \& Ladman (1950) for their Group A mice. While times could be identified by which no more than $50 \%$ of the mice in Groups B-F had ovulated, such was not true for their Group A animals: at hourly intervals, beginning at 13:00 h, $0,75,100,57,75,70,67,83$ and $100 \%$, respectively, of different subgroups of Group A were found to have ovulated. These observations seem to suggest that the majority of the Group A animals tended to ovulate shortly after the time at which those of Group F did (comparable to the Group A early ovulators in the present study), while a small proportion ovulated much later, at about the same time at which most of their Group B mice ovulated, yet still considerably earlier than did the Group A late ovulators and Group B mice in the present study.

The time-of-ovulation data for Swiss and $C D^{*}-1$ mice seem to suggest that, depending on the time of parturition, some mice may release $\mathrm{LH}$ at that time whereas others may delay the release of LH for several hours. Measurements of $\mathrm{LH}$ concentrations in the plasma of $\mathrm{C}$ strain mice within the 24-h period after parturition (Murr, Geschwind \& Bradford, 1973) showed that LH levels were higher than those found on the day of dioestrus (i.e. $>4 \mathrm{ng} / \mathrm{ml}$ ) in about one-third to one-half the animals killed at each 3-h interval between 08:00 and 20:00 h; individual values ranged between $<4 \mathrm{ng} / \mathrm{ml}$ and $>96 \mathrm{ng} / \mathrm{ml}$. The mice studied were those which had given birth between 20:00 and 08:00 h, a time including Groups A, B and most of Group C of the present study, but the times of ovulation were not reported. Specific correlations for times of parturition, times of LH release, and times of post-partum ovulation in the mouse still need to be established. Since (a) parturitions in $C D^{*}-1$ mice have been shown to be comparably distributed throughout both the light and dark periods under 3 different $\mathrm{L}: \mathrm{D}$ ratios, and (b) the time of ovulation in the majority of these mice appears to be reasonably predictable relative to their respective time of littering, this strain would appear to be useful for investigating the hormonal events associated with the time of post-partum ovulation, i.e. exploration of whether $C D^{*}$ - 1 mice giving birth close to the time of 'lights off' release $\mathrm{LH}$ at the time of parturition and whether those littering closer to the time of 'lights on' have a delay in release of $\mathrm{LH}$.

This investigation was supported in part by two University of Illinois Graduate College Research Board Grants, I/C 2-41-35-30-3-08 and CRR 2-41-35-30-3-01.

\section{References}

Biggers, J.D., Curnow, R.N., Finn, C.A. \& McLaren, A. (1963) Regulation of the gestation period in mice. $J$. Reprod. Fert. 6, 125-138.

Bingel, A.S. (1968) The timing of cyclic and post-partum ovulation in the mouse. Ph.D. thesis, University of Illinois, Chicago.
Bingel, A.S. \& Schwartz, N.B. (1969a) Pituitary LH content and reproductive tract changes during the mouse oestrous cycle. J. Reprod. Fert. 19, 215-222.

Bingel, A.S. \& Schwartz, N.B. (1969b) Timing of LH release and ovulation in the post partum mouse. $J$. Reprod. Fert. 19, 231-237. 
Edwards, R.G. \& Gates, A.H. (1959) Timing of the stages of the maturation divisions, ovulation, fertilization, and the first cleavage of eggs of adult mice treated with gonadotrophins. J. Endocr. 18, 292-304.

Hashizume, K., Sugawara, S. \& Takeuchi, S. (1973) Studies on the reproductive phenomena in the post-partum rat. I. Time of delivery and post-partum ovulation in rat. Tohoku J. agric. Res. 24, 117-122.

Hoffmann, J.C. \& Schwartz, N.B. (1965) Timing of post-partum ovulation in the rat. Endocrinology 76, $620-625$.

Johnson, N.P. (1972) Postpartum ovulation in the rat. Ph.D. thesis, Purdue University, Lafayette.

Mainland, D., Herrera, L. \& Sutcliffe, M.I. (1956) Statistical tables for use with binomial samplescontingency tests, confidence limits, and sample size estimates, p. 18. N.Y. University College of Medicine, New York.
Morishige, W.K., Pepe, G.J. \& Rothchild, I. (1973) Serum luteinizing hormone, prolactin, and progesterone levels during pregnancy in the rat. Endocrinology 92, 1527-1530.

Murr, S.M., Geschwind, I.I. \& Bradford, G.E. (1973) Plasma LH and FSH during different oestrous cycle conditions in mice. J. Reprod. Fert. 32, 221-230.

Rebar, R.W., Nakane, P.K. \& Midgley, A.R., Jr (1969) Post-partum release of luteinizing hormone $(\mathrm{LH})$ in the rat as determined by radioimmunoassay. Endocrinology 84, 1352-1358.

Runner, M.N. \& Ladman, A.J. (1950) The time of ovulation and its diurnal regulation in the postparturitional mouse. Anat. Rec. 108, 343-361.

Ying, S.-Y., Gove, S., Fang, V.S. \& Greep, R.O. (1973) Ovulation in postpartum rats. Endocrinology 92, $108-116$.

Received 17 July 1981 